\section{Zuriah}

Jurnal Pendidikan Anak Usia Dini
Volume 1, Nomor 2, 2020

ISSN 2746-0797 (p), 2746-0800 (e)

http://journal.iaincurup.ac.id/index.php/paud

DOI: $10.29240 /$ zuriah.v1i2.2019 | p. 83-96

\title{
Pendidikan Perilaku Hidup Sehat dan Bersih Perspektif Pendidikan Islam Bagi Anak Usia Dini dalam Kenormalan Baru Covid-19
}

\author{
Muhammad Taufiqurrahman \\ Institut Agama Islam Negeri Bengkulu, Indonesia \\ taufiq@iainbengkulu.ac.id
}

\begin{abstract}
This article aims to find out how to educate healthy and clean living behaviors in the perspective of Islamic education for early childhood in facing the new normal of Covid19 which is still continuing today. The method employed is library research that used the Prohpetic Parenting book entitled "Cara Nabi Mendidik. Anak. (How the prophet educates His children) as the main reading material. Then, the data was analyzed in a literary way by looking for other books or journals that are relevant to the theme discussed. The results reveal that educating children on clean and healthy living habits in their early childhood can be done with two approaches. First, it can be a habitual approach where parents get children to do activities that support health and bygiene in accordance to the Qur'an and hadith in facing new normal such as maintaining health, hand and mouth hygiene, food intake, and a resting pattern. Second, the method approach is that parents must use the right method to show them how to do this habituation. The uswah al hasanah method can be an option for parents to invite children to have a bealthy and clean lifestyle in facing this current situation of Covid-19. Therefore, parents must become role models for children in implementing clean and healthy living behaviors along the lines of Qur'an and hadith.
\end{abstract}

Keywords: PHBS, Early Childhood Education, Islamic Education, New Normal, Covid-19

\begin{abstract}
Abstrak
Tulisan ini bertujuan untuk mengetabui bagaimana pendidikan perilaku bidup sehat dan bersib perspektif pendidikan Islam bagi anak usia dini dalam menghadapi kenormalan baru Covid-19 yang masih berlanjut hingga saat ini. Metode yang digunakan dalam penelitian ini adalah library reseacrh dengan menggunakan buku Prohpetic Parenting Cara Nabi Mendidik. Anak sebagai bahan bacaan utama kemudian data ditelaah dan dianalisis dengan cara literer yakni mencari buku atau jurnal lainnya yang relevan dengan tema yang dibahas. Hasil dari analisis literer yang dilakukan bahwa dalam perspektifpendidikan Islam pendidikan perilaku bidup bersib dan sehat bagi anak usia dini dapat dilakukan
\end{abstract}


dengan dua pendekatan. Pertama menggunakan pendekatan pembiasaan dimana orang tua membiasakan anak untuk melakukan kegiatan yang menunjang kesehatan dan kebersiban yang sesuai dengan Al-Qur'an dan hadis dalam menghadapi kenormalan baru seperti menjaga kesehatan, menjaga kebersiban tangan dan mulut, menjaga asupan makanan dan menjaga pola istirahat. Kedua, pendekatan metode yakni orang tua harus menggunakan metode yang tepat untuk. mendidik anak usia dini melakukan pembiasaan tersebut. Metode uswah al hasanah dapat menjadi pilihan bagi orang tua untuk mengajak anak berperilaku bidup sehat dan bersih dalam menghadapi kenormalan baru Covid-19. Orang tua harus menjadi role model bagi anak dalam menerapkan perilaku bidup bersih dan sehat sesuai tuntunan Al-Qur'an dan hadis.

Kata Kunci: PHBS, Pendidikan Anak Usia Dini, Pendidikan Islam, Kenormalan Baru, Covid-19.

\section{A. PENDAHULUAN}

Perkembangan kasus covid-19 di Indonesia terus mengalami peningkatan yang signifikan. Data terakhir menunjukkan ada 3.444 kasus baru Covid-19 di Indonesia, hingga saat ini penambahan jumlah keseluruhan suspek positif Covid-19 mencapai 194.109 orang (Hakim, 2020). Hal tersebut juga menimpa anak-anak sebagai suspek positif. Jika merujuk data Satgas Penanganan COVID-19, per 2 September 2020 tercatat 7.616 orang meninggal dunia akibat COVID-19, dan 7.281 orang meninggal itu diketahui umurnya. Dari 7.281 kasus kematian tersebut, 58 di antaranya adalah anak usia 0-5 tahun dan 87 kematian lainnya menimpa anak usia 6-17 tahun. Artinya 1,9 persen kematian akibat COVID-19 di Indonesia menimpa anak-anak (Bernie, 2020).

Berdasarkan data tersebut pemerintah tetap menganjurkan agar masyarakat tetap menjaga kebersihan diri dan keluarga serta menjaga jarak, menghindari kerumunan dan menggunakan alat pelindung diri seperti masker, handsanitizer, face shield dan lain sebagainya. Hal tersebut bertujuan untuk mengurangi resiko penyebaran virus covid-19, terlebih dalam lingkungan keluarga. Menjaga kebersihan merupakan salah satu ajaran Islam yang sangat mendasar. Keluarga menjadi central utama dalam mengajarkan dan mendidik anak dalam berperilaku hidup sehat sesuai ajaran agama Islam. Kebersihan dalam Islam menjadi pembahasan awal yang harus diketahui dan dilaksanakan oleh keluarga.

Pengajaran dan pendidikan mengenai hidup sehat dapat dilakukan oleh orang tua kepada anak saat usia dini. Sesuai dengan anjuran yang ada dalam buku Propethic Parenting Cara Nabi Mendidik. Anak, sejatinya usia dini 
adalah usia dimana anak akan merekam dan mengingat setiap yang dipelajarinya hingga anak tersebut beranjak dewasa. Pada periode ini, anak berada pada fase yang sangat penting dalam pertumbuhan otak, intelegensi, kepribadian, memori dan aspek perkembangan lainnya yang dikenal dengan fase "Golden Age". Sebagai pendidik, orang tua harus mampu memaknai fase golden age sebagai fase yang perlu mendapatkan perhatian dan treatment yang tepat agar anak mampu melewati tugas perkembangannya dengan baik. Pendidikan anak usia dini tidak hanya terpaut pada pengetahuan saja melainkan mencakup pada pengasuhan, perlindungan dan kesehatan anak, karena hal tersebut akan berpengaruh terhadap tahap perkembangannya (Taufiqurrahman, 2018).

Seperti penelitian yang dilakukan oleh I Gusti Lanang Agung Wiranata mengenai penerapan positive parenting dalam pembiasaan pola hidup bersih pada anak usia dini bahwa positive parenting merupakan pola asuh yang berlandaskan kasih sayang, perhatian, saling menghargai serta membangun hubungan baik antara orang tua dan anak. Hal tersebut bertujuan untuk mengajarkan bagaimana anak harus menjaga kesehatan diri nya dengan rajin mencuci tangan, menggosok gigi, memotong kuku dan menjaga kebersihan lingkungan rumah (Wiranata, 2020). Sejalan dengan itu Euis Kurniati, dkk. juga melihat pendidikan kesehatan bagi anak sangat penting pada masa pandemi covid-19 seperti saat ini. Salah satu hal yang dapat dilakukan orang tua adalah mengingatkan anaknya untuk selalu menjaga kesehatan dan mengikuti protokol kesehatan agar meminimalisir penyebaran virus covid-19. Selain itu juga orang tua harus memberikan contoh perilaku hidup sehat sebagai bentuk tanggungjawabnya terhadap anak (Kurniati, Nur Alfaeni, \& Andriani, 2020).

Pendidikan hidup bersih dan sehat juga menarik perhatian La Ode Anhusadar dan Islamiyah, keduanya memotret bagaimana orang tua menerapkan pendidikan hidup bersih dan sehat terhadap anak usia dini ditengah pandemi Covid-19 ini. Hasil penelitian bahwa penerapan perilaku hidup bersih dan sehat anak usia dini dalam kategori sangat baik, dari data Sebanyak 100\% atau 51 responden anak cuci tangan dengan sabun sebelum makan. Sebanyak $98 \%$ atau 50 responden anak jika keluar rumah menggunakan masker dan sebanyak $2 \%$ atau 1 responden anak jika keluar rumah tidak menggunakan masker. Sebanyak 100\% atau 51 responden anak jika sudah kembali kerumah langsung mandi dan 
mengganti baju dan sebanyak $100 \%$ atau 51 responden anak suka berjemur di pagi hari (Anhusadar \& Islamiyah, 2020). Melihat berbagai penelitian terkait dengan pendidikan perilaku hidup bersih dan sehat bagi anak usia dini, maka peneliti tertarik melihat bagaimana pendidikan Islam memandang tema ini dan menganalisisnya menjadi sebuah kajian mengenai pendidikan perilaku hidup sehat dan bersih dalam perspektif pendidikan Islam bagi anak usia dini dalam kenormalan baru covid-19.

\section{B. METODE PENELITIAN}

Metode yang digunakan dalam penelitian ini adalah kajian pustaka atau library research dengan cara mengutip pendapat dari sumber utama yakni buku Prophetic Parenting Cara Nabi Mendidik. Anak karya Nur Abdul Hafizh Suwaid, kemudian ditelaah dan dianalisis. Untuk pengumpulan data pada naskah ini digunakan metode pengumpulan data literer, yakni dengan terlebih dahulu menelusuri buku-buku atau jurnal-jurnal ilmiah yang ada relevansinya dengan topik yang dibahas. Kemudian ditelaah, dianalisis dan dibahas sesuai dengan temuan yang ada.

\section{HASIL DAN PEMBAHASAN}

Kewajiban orang tua dalam mendidik anak-anak dan keluarga telah dijelaskan dalam Al-Qur'an

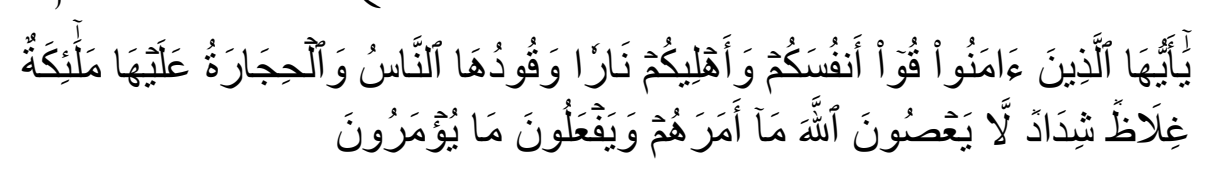

Hai orang-orang yang beriman, peliharalah dirimu dan keluargamu dari api neraka yang bahan bakarnya adalah manusia dan batu; penjaganya malaikat-malaikat yang kasar, keras, dan tidak mendurhakai Allah terhadap apa yang diperintabkan-Nya kepada mereka dan selalu mengerjakan apa yang diperintabkan. (QS. At-Tabrim: 6).

Dalam Kitab al-Kasysyaf kata "Peliharalah Dirimu" bermakna dengan meninggalkan kemaksiatan dan mengerjakan ketaatan. Juga untuk keluarga, harus diperlakukan sama dengan memperlakukan diri sendiri. Oleh karena itu, perlu ada usaha dan kerja keras secara terus menerus dalam mendidik anak, memperbaiki kesalahan mereka dan membiasakan mereka mengerjakan kebaikan. (Suwaid, 2014). 
Selanjutnya Ibnu Qayyim mengatakan bahwa barang siapa yang dengan sengaja tidak mengajarkan apa yang bermanfaat bagi anaknya dan meninggalkannya begitu saja, berarti dia telah melakukan suatu kejahatan yang besar. Kerusakan pada diri anak kebanyakan datang dari sisi orang tua yang meninggalkan mereka dan tidak mengerjakan kewajibankewajiban dalam agama. Para orang tua melalaikan mereka diwaktu kecil, sehingga mereka tidak mampu menjadi orang yang bermanfaat bagi diri mereka sendiri dan tidak dapat memberi manfaat kepada orang tua mereka. (Suwaid, 2014).

Sejalan dengan Al-Gazali dalam konsep pendidikan mengatakan bahwa pendidikan agama harus dimulai sejak usia dini. Hal tersebut berdasarkan keadaan anak siap untuk menerima aqidah-aqidah agama semata-mata atas dasar iman, tanpa meminta dalil untuk menguatkannya, atau menuntut kepastian dan penjelasan. Oleh karena itu, dalam mengajarkan agama kepada anak-anak, hendaknya dimulai dengan menghafal kaidah-kaidah dan dasar-dasarnya. Setelah itu baru guru menjelaskan maknanya, sehingga mereka memahami, meyakini dan membenarkannya. (Al-Qalami, 2003).

Anak usia dini menurut al-Gazali seharusnya dikenalkan dengan agama. Karena manusia dilahirkan telah membawa agama sebagaimana agama yang dibawa oleh kedua orang tuanya (ayah-ibu). Oleh karena itu seorang anak akan mengikuti agama kedua orang tua serta guru. Konsep ini menjadikan kedua orang tua sebagai pendidik yang utama menjadi kekuatan dalam diri anak, agar anak tumbuh dan kembang ke arah penyucian jiwa, berakhlak yang mulia bertakwa dan diharapkan menyebarkan keutamaan ke seluruh umat manusia. (Al-Qalami, 2003).

Kewajiban orang tua dalam mendidik anak usia dini dapat dimulai dengan pendidikan hidup bersih dan sehat sesuai dengan ajaran Islam. Pelaksanaan Perilaku Hidup Bersih dan Sehat (PHBS) adalah sekumpulan perilaku yang dipraktekkan atas dasar kesadaran sebagai hasil pembelajaran. Pembelajaran yang dilakukan bertujuan menjadikan anakanak mampu menolong diri sendiri di bidang kesehatan (Aulina, 2018).

Selain itu pola tersebut (PHBS) mempunyai maksud untuk memotivasi anak-anak untuk berperan penting dalam mewujudkan kesehatan kebugaran (jasmani) atau kesehatan tubuhnya, guna terwujudnya hal tersebut maka di dilaksanakan pengembangan sistem kesehatan yang baik. Salah satu yang menjadi sasaran pengembangan 
lingkungan kesehatan tidak lain adalah keluarga, karena keluarga merupakan lingkungan awal dimana anak usia dini mendapatkan pendidikan dan bimbingan dari orang tua (Tabi'in, 2020).

Pendidikan perilaku hidup bersih dan sehat perspektif pendidikan Islam dapat dilakukan oleh orang tua yang berperan sebagai pendidik dalam keluarga, dengan beberapa bentuk pendekatan diantaranya:

\section{Pendekatan Pembiasaan}

Pendekatan pembiasaan yang dimaksud adalah orang tua harus membiasakan beberapa bentuk kegiatan dalam menjaga kesehatan dan kebersihan anak sebagai upaya menjaga diri dari penyebaran virus Covid-19 di masa kernomalan baru seperti saat ini. Kegiatan tersebut merupakan sunnah Nabi Muhammad Saw yang dapat dilakukan, yakni:

a. Membiasakan Olah Raga Untuk Anak

Olah raga dapat membangun jasmani anak untuk menjadi lebih kuat dalam menghadapi suatu penyakit, termasuk virus Covid-19. Dengan berolahraga tubuh dapat memproduksi antibodi yamg dapat mencegah masuknya bibit penyakit kecuali apabila Allah Swt menghendaki hal yang lain dan ujian yang lain. (Suwaid, 2014)

Para ulama mengetahui dengan pasti pentingnya bermain pada anak dan membentuk jasmani anak. Al-Ghazali mengemukakan bahwa setelah selesai sekolah, seorang anak harus diizinkan bermain dengan permainan yang baik sebagai penyegaran setelah capek belajar. Bermain bagi anak dapat diartikan sebagai bagian dari olahraga. Melarang seorang anak bermain dan memaksanya untuk terus belajar dapat mematikan hati, merendahkan kecerdasan dan menyebabkan kehidupannya terasa sempit, sehingga dia akan mencari cara untuk bisa lepas dari itu semua walau dengan tipu daya (Suwaid, 2014). Kemudian diriwayatkan dari Umar bin Khatab :

"Ajarkanlan kepada anak-anak kalian berenang, memanah dan tetap duduk di punggung kuda yang sedang melompat"

Dari atsar ini menjadi jelaslah hak anak untuk diajari beberapa jenis olahraga tertentu yang disebutkan secara khusus oleh Nabi Saw. Ini menunjukkan bahwa olahraga tersebut memiliki peran penting dalam diri anak pada masa sekarang dan 
akan datang. Untuk itu orang tua hendaknya perlu mengajarkan anak minimal salah satu dari ketiga cabang olahraga tersebut. Seperti berenang, orang tua dapat mengajarkan anak berenang di rumah, dengan menggunakan kolam buatan, hal ini disamping menjalankan protokol kesehatan Covid-19 untuk Stay at home, juga sekaligus mengajarkan anak olahraga yang dapat meningkatkan kesehatan jasmaninya.

\section{Membiasakan Anak Bersiwak}

Perhatian Nabi Saw. terhadap siwak dapat diketahui melalui sabdanya

\footnotetext{
لو لا ان أثق على أمتي لامرتهم بالسو الك عند كل صلاه

"kalau seandainya tidak memberatkan bagi umatku, tentu aku perintabkan mereka untuk bersiwak pada setiap shalat"
}

Apabila seorang anak terbiasa melakukan kebiasan ini dan membersihkan gigi secara berkala dan terus menerus, otomatis dia telah mencegah banyak penyakit yang timbul akibat kotornya gigi atau gusi berdarah. Selain siwak pada zaman sekarang anak dapat menggosok gigi dengan menggunakan pasta gigi yang mudah didapatkan. Orang tua hendaknya menyediakan keperluan menyikat gigi anak ditiap rumah.

\section{Menjaga Kebersihan Kuku}

Seorang anak yang terbiasa memotong kuku, berarti dia telah melindungi kedua tangannya dari berbagai kotoran yang melekat di bawah kuku yang dapat menyebabkan penyakit, karena setelah tidak sadar si anak sering kali memasukkan tangan ke dalam mulutnya. Selain itu men

\section{Mengikuti Sunnah Nabi dalam Makan dan Minum}

Dalam ilmu kesehatan atau gizi disebutkan, makanan adalah unsur terpenting untuk menjaga kesehatan. Cuci tangan sebelum makan juga merupakan salah satu materi dalam pendidikan hidup bersih dan sehat. Menurut Novitasari, banyak anak usia dini terutama di PAUD Mutiara Cendikia yang belum memahami tata cara cuci tangan menggunakan sabun dengan benar, maka dari itu mereka mengadakan penyuluhan mengenai perilaku hidup bersih dan sehat. Hasilnya setelah dilakukan penyuluhan, anak usia dini, guru dan orang tua memiliki pemahaman yang benar mengenai cuci tangan 
menggunakan sabun dalam menjaga kebersihan tangan sebelum beraktivitas (Novitasari, 2018).

Tangan adalah organ tubuh yang paling sering terkontaminasi bakteri melalui sentuhan atau pegangan, Oleh karena mencuci tangan dengan air yang mengalir menjadi langkah pertama dalam pola hidup dan makan sehat. Mencuci tangan dengan sabun sebelum makan, akan menurunkan kejadian diare sampai 47\% dan insfeksi saluran pernafasan atas (ISPA). Sebesar $30 \%$, bahkan, penyakit penyakit inspeksi lain yang lebih berbahaya.seperti hepatitis A,Toxoplasmosis termasuk juga virus Covid-19, dapat dicegah penularannya dengan mencuci tangan dengan benar sebelum makan (Anam, 2016).

Makan makanan yang halalan dan thayyiban. Al- Quran berpesan agar manusia memperhatikan yang dimakannya, seperti ditegaskan dalam ayat:

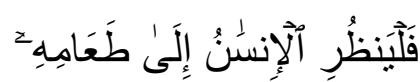

"maka hendaklah manusia itu memperhatikan makanannya". (QS. Abasa 80:24).

Menu makanan yang berfaedah terhadap kesehatan jasmani, seperti tumbuh- tumbuhan, daging binatang darat, daging binatang laut, segala sesuatu yang dihasilkan dari daging, madu, kurma, susu, dan semua yang bergizi. Allah menyatakan:

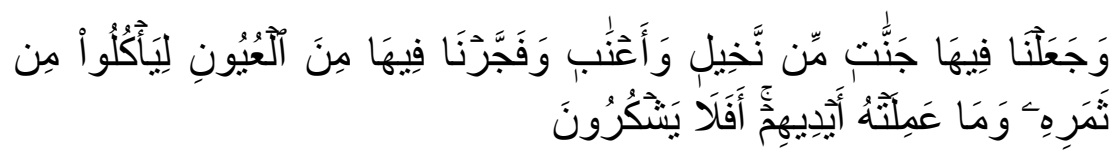

Dan Kami jadikan kepadanya kebun- kebun kurma dan anggur dan pancarkan padanya beberapa mata air, supaya mereka makan dari buabnya, dan dari apa yang diusahakan oleh tangan mereka. Maka mengapakah mereka tidak bersyukur" (QS Yaasin ayat 34-35).

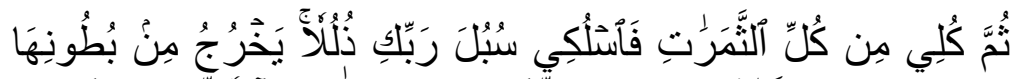

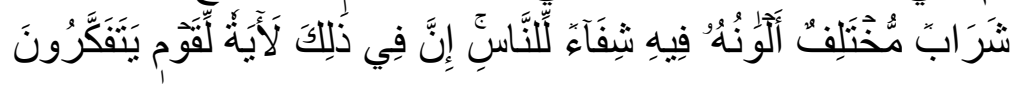

Kemudian makanlah dari tiap-tiap (macam) buab-buahan dan tempublah jalan Tubanmu yang telah dimudabkan (bagimu). dari perut lebah itu ke luar minuman (madu) yang bermacam-macam warnanya, di 
Muhammad Taufiqurrahman : Pendidikan Perilaku Hidup Sehat dan Bersih |91

dalamnya terdapat obat yang menyembubkan bagi manusia. Sesunggubnya pada yang demikian itu benar-benar terdapat tanda (kebesaran Tuhan) bagi orang-orangyang memikirkan. (QS. An-Nabl69).

Menjalani kehidupan dalam kenormalan baru Covid-19 menjadikan orang tua menjaga asupan makanan untuk anak usia dini agar kesehatannya tetap terjaga. Hal tersebut sesuai dengan firman Allah Swt diatas, memakan makanan yang halal dan bergizi sangat dianjurkan untuk meningkatkan kesehatan keluarga. Selain itu anjuran untuk terus menjaga kebersihan tangan dengan rutin mencuci tangan dan menggunakan handsinitizer harus tetap diajarkan kepada anak untuk mengurangi resiko penularan virus Covid-19.

\section{Melatih Anak Tidur dalam Posisi Miring ke Kanan}

Ini juga merupakan salah satu dasar ajaran Nabi Saw. yang berkaitan dengan kesehatan dalam kehidupan seorang muslim. Cara tidur seperti ini memiliki manfaat kesehatan yang banyak, sebagaimana wasiat Nabi kepada para sahabat yang diriwayatkan oleh Bukhari dan Muslim (Suwaid, 2014) :

Nabi Saw bersabda, apabila engkau bendak berbaring di tempat tidurmu, berwudhulah seperti wudhumu untuk shalat, kemudian berbaringlah miring ke sebelah kanan dan bacalab "Ya Allah, aku menyerabkan diriku kepada-Mu, aku serabkan segala urusan-ku padaMu dan aku perlindungkan punggungku kepada-Mu dengan mengharap dan takut pada-Mu. Tidak ada tempat berlindung dan keselamatan dari-Mu selain kepada-Mu. Aku beriman kepada kitab-kitab-Mu yang Engkau turunkan dan Nabi-Mu yang Engkau utus. Jadikanlah bacaan ini bacaan terakhir yang engkau ucapkan."

Setelah membahas kegiatan olahraga, menjaga kebersihan diri dan pola makan sesuai dengan sunnah Nabi, orang tua juga perlu mengetahui dan memahami tentang pola tidur anak sesuai dengan ajaran Islam. Tidur merupakan istirahat paling baik bagi tubuh untuk mengembalikan stamina setelah seharian beraktivitas. Menjaga pola tidur anak dengan baik akan meningkatkan imunitas tubuh anak. Pola tidur yang baik menurut ajaran Nabi Saw adalah anak dilatih untuk 
tidur setelah shalat isya dan bangun dini untuk melaksanakan shalat subuh.

Apabila anak usia dini dibiasakan bangun pagi-pagi untuk ikut salat subuh tepat waktu, maka akan menguatkan jasmani serta rohaninya. Karena gas ozon menyebar di udara pada waktu subuh. Gas tersebut dapat membantu melancarkan metabolisme tubuh dan membunuh banyak jenis bibit penyakit. Seorang anak yang menghirup gas ini, secara tidak sadar ia telah memperkuat sistem metabolisme tubuhnya di samping mengerjakan perintah shalatnya (Suwaid, 2014) hal ini juga berlaku di saat pandemi seperti sekarang ini. Bangun pagi untuk meningkatkan imunitas tubuh dengan berolahraga ringan bersama-sama anggota keluarga di sekitar lingkungan rumah.

\section{Pendekatan Metode}

Dalam menerapkan pembiasan diatas, orang tua perlu menentukan metode yang tepat agar anak usia dini dapat menerima dan menjalankan kegiatan tersebut dengan ceria dan menyenangkan. Terlebih saat ini masih dalam kondisi pandemi Covid-19 yang mengharuskan semua kegiatan sosial-pendidikan lebih banyak dilaksanakan dirumah atau dikenal dengan istilah work from bome dan kenormalan baru sesuai dengan protokol kesehatan. Ririn mengungkapkan bahwa ada beberapa masalah yang muncul akibat WFH seperti emosi tidak stabil yang akan berdampak terhadap orang tua dan anak (Wiresti, 2020).

Menjaga kesehatan dimasa pandemi covid-19 ini menjadi keniscayaan tidak terkecuali bagi anak usia dini. Pemilihan metode dalam mendidik anak berperilaku hidup bersih dan sehat sesuai ajaran Islam menjadi sesuatu yang urgent bagi orang tua, karena tanggungjawabnya sebagai pendidik pertama bagi anak. metode yang dapat diterapkan oleh orang tua dalam mendidik anak usia dini berperilaku hidup bersih dan sehat dalam upaya menjaga diri dan keluarga dari virus Covid-19 salah satunya adalah metode Uswah AlHasanah.

Dalam pendidikan Islam penggunaan metode keteladanan atau uswah al-khasanah di dasari oleh faktor psikologis manusia yang memiliki kecenderungan untuk meniru atau mengimitasi. Allah Swt berfirman dalam surat al-Ahzab ayat 21 : 


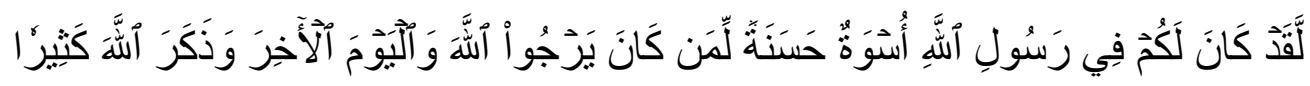
Sesunggubnya telah ada pada (diri) Rasulullah itu suri teladan yang baike bagimu (yaitu) bagi orang yang mengharap (rahmat) Allab dan (kedatangan) hari kiamat dan Dia banyak menyebut Allah.

Ayat diatas menjelaskan bahwa sebagai umat Muslim sudah seharusnya kita mengikuti atau meneladani Nabi Muhammad Saw. mulai dari ucapan, tingkah laku dan kebiasaan beliau. Menurut Taklimudin dan Febri pendidikan Islam merupakan proses pembentukan dan pembinaan perilaku anak melalui pengajaran, penghayatan, pengalaman terhadap ajaran Islam. Dalam pendidikan Islam dikenal suatu metode yakni metode keteladanan, dimana metode ini memudahkan anak untuk memahami dan mempraktekkan apa yang diajarkan oleh orang tua atau guru (Taklimudin \& Saputra, 2018).

Dengan adanya pendidikan keteladanan akan mempengaruhi individu pada kebiasaan, tingkah laku dan sikap. Dalam al-Qur'an kata teladan di proyeksikan dengan kata uswah yang kemudian diberi sifat dibelakangnya seperti sifat hasanah yang berati baik. Sehingga terdapat ungkapan uswatun hasanah yang berati teladan yang baik (Nata, 1997).

Dalam konteks pendidikan perilaku hidup bersih dan sehat, orang tua harus menjadi tauladan bagi anak. Karena anak usia dini adalah makhluk yang senang meniru. Orang tuanya merupakan figur dan idolanya. Bila mereka melihat kebiasaan baik dari ayah ibunya, merekapun akan dengan cepat mencontohnya. Orang tua yang berprilaku buruk akan ditiru perilakunya oleh anak-anak. Anak-anak pun paling mudah mengikuti kata-kata yang keluar dari mulut orang tua (Halim, 2008).

Menjaga kebersihan diri, lingkungan hingga menjaga kesehatan keluarga merupakan hal yang harus diajarkan kepada anak usia dini. Dengan kondisi kenormalan baru Covid-19 seperti ini, orang tua harusnya mengajak anak untuk bersama-sama menerapkan protokol kesehatan seperti rajin mencuci tangan, menggunakan handsinitizer, menggunakan masker bila keluar rumah, menjaga asupan makanan yang bergizi dan melakukan olahraga bersama, bukan hanya dengan perintah saja. 
Orang tua menjadi role model bagi anak selama pandemi ini, untuk selalu menjaga kesehatan dan kebersihan agar mengurangi penyebaran virus Covid-19. Karena sesungguhnya fase kanak-kanak merupakan fase yang paling cocok, paling panjang, dan paling penting bagi seorang pendidik menanamkan prinsip-prinsip yang baik, lurus dan pengarahan yang benar ke dalam jiwa dan prilaku anak-anaknya. Kesempatan untuk itu terbuka lebar, ditopang oleh sarana dan prasarana yang modern yang cukup tersedia di setiap lembaga pendidikan dan dilingkungan keluarga pada satu sisi. Di sisi lain, mengingat fase ini anak-anak masih memiliki fitrah yang suci, jiwa yang bersih, bakat yang jernih, dan hati belum terkontaminasi debu dosa dan kemaksiatan (Mustofa, 2019). Pada dasarnya, anak usia dini sangat memerlukan sosok teladan dan panutan yang mampu mengarahkan untuk melaksanakan perilaku hidup bersih dan sehat dalam kenormalan baru Covid-19 seperti saat ini.

\section{KESIMPULAN}

Pendidikan perilaku hidup bersih dan sehat perspektif pendidikan Islam bagi anak usia dini dapat dilakukan melalui berbagai kegiatan sesuai dengan landasan pendidikan Islam yakni Al-qur'an dan Hadis. Beberapa kegiatan tersebut diantaranya dengan menjaga kesehatan jasmani, menjaga kesehatan dan kebersihan tangan serta mulut, menjaga asupan makanan serta menjaga pola istirahat. Semua kegiatan tersebut diajarkan oleh orang tua melalui metode yang tepat dan menyenangkan. Salah satu metode yang dapat digunakan oleh orang tua dalam perspektif Islam adalah metode keteladanan (Uswah Al-Hasanah). Metode ini memberikan kesempatan kepada orang tua untuk menjadi role model bagi anak usia dini dalam menerapkan perilaku hidup bersih dan sehat.

Harapannya orang tua menjadi sosok teladan yang baik bagi anak usia dini dalam menjalankan perilaku hidup sehat pada masa kenormalan baru Covid-19 ini. Keluarga bisa menjadi skup terkecil untuk mengajarkan dan mendidik anak mengenai protokol kesehatan dan menjaga kesehatan keluarga agar mengurangi penyebaran virus Covid-19. Keteladan orang tua tidak hanya mengenai perilaku hidup bersih dan sehat semata, lebih dari itu orang tua harus memberikan pengetahuan, pengajaran dan pengalaman kepada anak usia dini, karena keluarga adalah sekolah pertama bagi anak. 


\section{REFERENSI}

Al-Qalami, A. F. (2003). Ringkasan Ihya 'Ulumudin Imam Al-Ghazali. In Gitamedia Press. https://doi.org/10.1017/CBO9781107415324.004

Anam, K. (2016). Pendidikan Perilaku Hidup Bersih Dan Sehat Dalam Presfektif Islam. Jurnal Sagacious.

Anhusadar, L., \& Islamiyah. (2020). Penerapan Perilaku Hidup Bersih dan Sehat Anak Usia Dini di Tengah Pandemi Covid 19. Jurnal Obsesi: Jurnal Pendidikan Anak Usia Dini. https://doi.org/10.31004/obsesi.v5i1.555

Aulina, C. N. (2018). Peningkatan Kesehatan Anak Usia Dini dengan Penerapan Perilaku Hidup Bersih dan Sehat (PHBS) di TK Kecamatan Candi Sidoarjo. AKSIOLOGIYA: Jurnal Pengabdian Kepada Masyarakat. https://doi.org/10.30651/aks.v3i1.1480

Bernie, Mohammad. 2020. Tirto.id "Kematian Anak Akibat Corona di Indonesia 10 Kali Lipat Dibanding AS", https://tirto.id/f3fa kematian-anak-akibatcorona-di-indonesia-10-kali-lipat-dibanding-as-f3fa

Fathani, A. H. (2008). Ensiklopedi hikemah: memetik buah kehidupan di kebun hikmah. Darul Hikmah

Kurniati, E., Nur Alfaeni, D. K., \& Andriani, F. (2020). Analisis Peran Orang Tua dalam Mendampingi Anak di Masa Pandemi Covid-19. Jurnal Obsesi : Jurnal Pendidikan Anak Usia Dini. https://doi.org/10.31004/obsesi.v5i1.541

Mustofa, A. (2019). Metode Keteladanan Perspektif Pendidikan Islam. Cendekia : Jurnal Studi Keislaman. https://doi.org/10.37348/cendekia.v5i1.71

Nata, A. Filsafat Pendidikan Islam I Jakarta; Logos Wacana Ilmu, 1997). Paradigma Pendidikan Islam, Kapita Selekta Pendidikan Islam

Novitasari, Y. (2018). Penyuluhan Program Perilaku Hidup Bersih Dan Sehat (Phbs) Melalui Kegiatan Cuci Tangan Pakai Sabun Pada Pendidikan Anak Usia Dini. Jurnal Pengabdian Masyarakat Multidisiplin. https://doi.org/10.36341/jpm.v2i1.573

Hakim, Rakhmat Nur.2020.Kompas.com dengan judul, UPDATE: Bertambah 3.444, Kini Ada 194.109 Kasus Covid-19 di Indonesia, Klik untuk baca: https://nasional.kompas.com/read/2020/09/06/15514501/updat e-bertambah-3444-kini-ada-194109-kasus-covid-19-diindonesia?page=all

Suwaid, M. N. A. H. (2014). Prophetic Parenting: Cara Nabi SAW Mendidik Anak. In Yogyakarta: Pro-U Media Alam Raya Enterprise Sdn. Bhd Pustaka Saujana Sdn. Bhd. https:/ /doi.org/978-967-568828-7 
96 | ZURIAH : Jurnal Pendidikan Anak Usia Dini, Vol. 1 No. 2, 2020

Tabi'in, A. (2020). Perilaku Hidup Bersih Dan Sehat(Phbs) Pada Anak Usia Dini Sebagai Upaya Pencegahan Covid 19. Jea (Jurnal Edukasi AUD). https://doi.org/10.18592/jea.v6i1.3620

Taklimudin, T., \& Saputra, F. (2018). Metode Keteladanan Pendidikan Islam dalam Persfektif Quran. BELAJEA: Jumal Pendidikan Islam. https://doi.org/10.29240/bjpi.v3i1.383

Taufiqurrahman, M. (2018). Prophetic Parenting Mencetak Pendidik Berkarakter Dalam Pendidikan Anak Usia Dini. Al Fitrab: Journal Of Early Childhood Islamic Education, 1(2), 90. https://doi.org/10.29300/alfitrah.v1i2.1336

Wiranata, I. (2020). Penerapan Positive Parenting Dalam Pembiasaan Pola Hidup Bersih Dan Sehat Kepada Anak Usia Dini. Pratama Widya: Jurnal Pendidikan 